\title{
Removal of Methylene Blue and Basic Yellow 28 Dyes from Aqueous Solutions using Sulphonated Waste Poly Methyl Methacrylate
}

Nadjib Dahdouh*a, Samira Amokrane ${ }^{\mathrm{a}}$, Ramón Murillo ${ }^{\mathrm{b}}$, Elhadj Mekatel $^{\mathrm{a}}$ and Djamel Nibou ${ }^{\mathrm{a}}$

${ }^{a}$ Laboratoire de Technologie des Matériaux, Université des Sciences et de la Technologie Houari-Boumediene, BP 32, El-Alia, Bab-Ezzouar, Alger, Algeria.

${ }^{b}$ Instituto de Carboquimica (CSIC), Energy and Environmental Dept., C/Miguel Luesma Casta'n No. 4, 50015 Zaragoza, Spain.

\begin{abstract}
This work focuses on two different environmental problems: the recovery of plastic wastes PMMA (W PMMA) and their application in the removal of textile dyes Methylene Blue (MB) and Basic Yellow 28 (BY28) in aqueous solutions. The selected waste plastic was upgraded to produce an adsorbent suitable for dyes removal. For that, the material was grinded cryogenically up to a particle size of less than $100 \mu \mathrm{m}$ and treated with sulfuric acid. The sulphonated waste PMMA (SW PMMA) was characterized by FTIR, scanning electronic microscopy (SEM) and chemical composition analysis $(\mathrm{C}, \mathrm{H}, \mathrm{N}, \mathrm{O}$ and $\mathrm{S}$ content). The formation of sulphonic groups in the material after sulphonation reaction has been successfully demonstrated by FTIR, and can be observed mainly in the region $3087 \mathrm{~cm}^{-1}$ to $3657 \mathrm{~cm}^{-1}$, where an intense band bound to the stretching of the $\mathrm{SO}_{3} \mathrm{H}$ appeared; another absorption band appeared in the region from $1080 \mathrm{~cm}^{-1}$ to $1271 \mathrm{~cm}^{-1}$ that corresponds to the symmetric stretching of the $\mathrm{SO}_{2}$ group. The effects of solution $\mathrm{pH}$, initial dyes concentration, adsorbent dose and temperature were studied in batch experiments. The obtained data showed that SW PMMA adsorbent exhibit significant adsorption capacities of 97.09 and $222.22 \mathrm{mg} \mathrm{\textrm {g } ^ { - }}$
\end{abstract}

\footnotetext{
${ }^{*}$ Corresponding author : Tel. +21321247955; Fax : +21321248008

E-mail: ndahdouh@usthb.dz (DAHDOUH Nadjib)
} 
${ }^{1}$ for MB and BY28 respectively. The complete removal of MB and BY28 on the SW PMMA was achieved in less than $45 \mathrm{~min}$. The Langmuir, Freundlich and Temkin models were applied and it was found that the equilibrium data could be satisfactory fitted to Langmuir adsorption isotherm. The kinetic study showed that the pseudo second order kinetic model correlates the experimental data. Furthermore, the thermodynamic parameters were determined for both dyes. As a result, the negative values of Gibbs free energy $\Delta \mathrm{G}^{\circ}$ indicated the spontaneity of the adsorption of MB and BY28 by SW PMMA. The negative values of $\Delta \mathrm{H}^{\circ}$ revealed the exothermic nature of the process and the negative values of $\Delta \mathrm{S}^{\circ}$ suggest the stability of MB and BY28 on the surface of SW PMMA.

Key words: Waste PMMA; Sulphonation; Removal; Dyes; Kinetic; Thermodynamic.

\section{Introduction}

Currently, we are living an environmental crisis that in the last decades has become a significant problem for our future development. It is well-known that human activity pollutes the environment by the emission of toxic gases, liquid effluents and the yearly production of millions of tons of solid wastes. Although some waste materials are biodegradable and can be absorbed by the environment in a short time, other residues are not biodegradable and may remain virtually unaltered during thousands of years. This is the case of many plastics that are products obtained by the petrochemical industry. Plastics have become an essential part of our modern lifestyle. Since more than 50 years ago, global plastics production has grown steadily due to their vast applications in many sectors. While in the early 1980s, global consumption of plastics amounted to about 65 million tons [1]. In 2005 global plastic consumption was reported to be 230 million tons [2]. 322 million tons of plastic were consumed in 2015 . Therefore, plastic consumption is an important source of waste [3, 4]. Major constituents of municipal solid waste are thermoplastic polymers that sometimes are difficult to be separated 
ending their life in incineration facilities and landfills [5]. Nowadays, Plexiglas namely Poly (methyl methacrylate) (PMMA) is a transparent thermoplastic often used in sheet form as a lightweight or shatter-resistant alternative material to glass. PMMA are a kind of important thermoplastic materials, due to its excellent properties (lightness, transparency, excellent resistance to atmospheric agents and safety), PMMA is widely used in the construction of buildings but also in the fields of electronics and automotive industry [6, 7]. PMMA has been widely employed in industrial and domestic appliances since it was commercialized in the beginning of the 1930s [8]. About 327000 tons of PMMA are consumed only annually in Western Europe with an increase of $4 \%$ per year [7]. After use, waste PMMA is commonly incinerated or dumped in landfills. However, other more environmentally friendly treatment processes should be studied. Among these processes, sulphonation is a chemical reaction that can generate new products from waste materials. The aim of this process is to introduce a sulfonic group $\mathrm{SO}_{3} \mathrm{H}$ on the carbon structure of a molecule. $\mathrm{H}_{2} \mathrm{SO}_{4}, \mathrm{SO}_{3}$ and its complexes are generally used as sulfonating agents [9]. The role of the attached sulfonic groups to the polymer chain is to increase its hydrophilicity and proton conductivity. In this way, they can also offer and retain relatively more water because of the improved antifouling ability and favorable hydrodynamic environment of the membrane [10]. Sulphonated waste polystyrene is already used in waste water treatment with good removal of heavy metals, maximum adsorption capacities were $5.01 \mathrm{mg} \mathrm{g}^{-1}, 31.92 \mathrm{mg} \mathrm{g}^{-1}$ and $53.25 \mathrm{mg} \mathrm{g}^{-1}$ for $\mathrm{Zn}^{2+}, \mathrm{Cd}^{2+}$ and $\mathrm{Pb}^{2+}$ respectively $[11,12]$. The purpose of our study is the use of the waste PMMA in the removal of textile dyes. This kind of compounds are relevant pollutants in the wastewater, mostly textile and tannery branches used it extensively. The textile industry uses nearly 30-50 L to produce $1 \mathrm{~kg}$ of tissue [13]. More than 10000 tons/year of textile dyes are consumed by textile industries worldwide and approximately $1 \%$ of dyes is discharged into waters stream [14]. In current dyeing processes up to $15 \%$ of the dyes used do not bind to the fibers and 
$50 \%$ lost in the wastewater, they are discharged into the sewage pipes and result in a serious pollution problem that makes the water more complex to be purified in the treatment plants $[15,16]$. Textile effluents have a dangerous and toxic effect on human health, aquatic organisms, plants and soil [17-20]. The presence of even very low concentrations of dyes in water reduces light penetration through the water surface, precluding photosynthesis of the aqueous flora [21-24]. Biological, chemical and physical treatment methods are conventional and advanced solutions present for the removal of textile wastewater [25], including adsorption is an effective technique for removal of dyes in water because of its high efficiency and ability to separate a wide range of chemical compounds [26-28]. The aim of the present paper is to demonstrate the feasibility of using new adsorbents obtained by the sulphonation of waste plastics to remove dyes in water effluents. The effect of various parameters such as initial dye concentration, $\mathrm{pH}$, dye dose and temperature were studied. The equilibrium isotherms are also estimated using Langmuir, Freundlich and Temkin models. Thermodynamic parameters, $\Delta \mathrm{H}^{\circ}$, entropy $\Delta \mathrm{S}^{\circ}$ and Gibbs free energy $\Delta \mathrm{G}^{\circ}$ for the removal of MB and BY28 on SW PMMA were also examined.

\section{Materials and methods}

\subsection{Sulphonation of waste PMMA}

Waste transparent Plexiglas pieces (Fig.1(a)) were manually washed with tap water and soap to remove the dust and impurities, then rinsed with distilled water and dried in air. The waste was grinded cryogenically using liquid nitrogen (powder fraction lower than $100 \mu \mathrm{m}$ ) (Fig.1(b)). After that, 10 grams of powder sample was placed into a flask containing $100 \mathrm{ml}$ of sulfuric acid (95-97\%). The mixture reacted for $2 \mathrm{~h}$ at $100{ }^{\circ} \mathrm{C}$ with constant stirring. Afterwards, a paste was produced that was filtered and washed with distilled water until 
neutral $\mathrm{pH}$ was measured. In this way, the residual sulphuric acid was removed from the powder. Then the sulphonated powder (Fig.1(c)) was dried in an oven at $90{ }^{\circ} \mathrm{C}$ for $2 \mathrm{~h}$.

\subsection{Characterization of SW PMMA}

The determination of the specific surface area and pore volume of SW PMMA was carried out by $\mathrm{N}_{2}$ physisorption at $77 \mathrm{~K}$ in an ASAP2020 (Micromeritics) apparatus and the density was obtained by using Helium pycnometry in an Accupyc 1340 (Micromeritics). The humidity was measured by thermogravimetric method: SW PMMA weighed before and after drying by heating up to $100^{\circ} \mathrm{C}$ in an oven. The loss of mass gave the moisture of the sample. The ultimate analysis of the samples was performed in a Thermo Flash 1112. To confirm the presence of sulfonic and sulfonate groups, infrared spectroscopy (FTIR) analyses were carried out in a Vertex 70 spectrometer (Bruker). The FTIR spectra of SW PMMA were recorded in the region 400 to $4000 \mathrm{~cm}^{-1}$. The surface morphology of modified SW PMMA was observed by Scanning electron microscopy SEM (Hitachi 3400N, equipped with EDX Röntec XFlash de Si (Li)).

\subsection{Determination of $p H_{P Z C}$ of $S W P M M A$}

To understand the adsorption mechanism of MB and BY28 on the SW PMMA surface. The point of zero charge (pHpzc) of the adsorbent was measured as cited by Aid et al and Ladjali et al $[29,30]$. This method consists in placing a series of beakers of $50 \mathrm{ml}$ of $\mathrm{KCl}(0.1 \mathrm{M})$ at different pHs varying from 2 to 10 in each beaker. Then, $50 \mathrm{mg}$ of SW PMMA are added and stirred for 48 hours. After filtration, the final $\mathrm{pH}$ of the supernatant is measured. The $\mathrm{pH}_{\mathrm{PZC}}$ is the point where the final $\mathrm{pH}$ plot based on the initial $\mathrm{pH}$, corresponds to the intersection of the $\mathrm{pH}_{\text {initial }}$ curve equal $\mathrm{pH}_{\text {final }}$ with the axis of the bisectors (Fig.2). It was found that (pHpzc) of SW PMMA adsorbent is equal to 6 . At $\mathrm{pH}=6$, the adsorbent is a neutral charge on its surface. If $\mathrm{pH}>6$, the $\mathrm{SW}$ PMMA is charged negatively and positively for $\mathrm{pH}<6$. 


\subsection{Cationic dyes and synthetic solutions}

MB and BY28 were chosen because of its various applications mostly in textile industries. Some of their characteristics are given in Table 1. Stock solutions with a concentration of 300 $\mathrm{mg} \mathrm{L}^{-1}$ were prepared by solving the appropriate amount of each MB and BY28 solutes in distilled water at room temperature. The solutions were stirred for 2 hours to ensure the full dissolution of both dyes. After that, they were stored at $20 \pm{ }^{\circ} \mathrm{C}$ and later used in all the experimental campaign.

\subsection{Removal experiments and analytic procedures}

The removal of MB and BY28 from synthetic solutions by SW PMMA was performed in a batch system. Diverse doses of SW PMMA were contacted with $100 \mathrm{ml}$ of MB and BY28 solutions at different concentrations and pHs. The mixtures were stirred for $60 \mathrm{~min}$. After removal experiments, residual $\mathrm{MB}$ and BY28 dyes were determined using UV-Vis Spectrophotometer (Optizen 2120UV). The Removal percentage of dyes was determined by the following equation (Eq. 1) [31]:

$$
\operatorname{Removal}(\%)=\frac{\left(\mathrm{C}_{\mathrm{o}}-\mathrm{C}_{\mathrm{e}}\right)}{\mathrm{C}_{\mathrm{o}}} \times 100
$$

The capacity $q_{e}\left(\mathrm{mg} \mathrm{g}^{-1}\right)$ was calculated by the following expression (Eq. 2) [32]:

$\mathbf{q}_{\mathbf{e}}=\frac{\left(\mathbf{C}_{\mathbf{o}}-\mathbf{C}_{\mathbf{e}}\right) \mathbf{V}}{\mathbf{m}}$

Where $C_{o}$ and $C_{e}$ are the initial and equilibrium concentrations of dye $\left(\mathrm{mg} \mathrm{L}^{-1}\right)$ respectively, $V$ is the volume of the dye solution (L) and $m$ is the mass of SW PMMA (g).

\section{Results and discussion}

\subsection{Characterization of solid samples}


Some physicochemical properties of SW PMMA adsorbent were determined and shown in Table 2. The SW PMMA has almost the same $\mathrm{pH}$ as distilled water $\mathrm{pH}_{\mathrm{pzc}}=6$. The density of the adsorbent is $2.68 \mathrm{~g} \mathrm{~cm}^{-3}$ and its moisture content is $6.6 \%$. This value is higher than that of sulphonated waste Polystyrene (SW PS) (3.85\%) reported by al Ruziwa et al [11]. The values for the specific surface area and pore volume of SW PMMA are $1.08 \mathrm{~m}^{2} \mathrm{~g}^{-1}$ and $0.25 \mathrm{~cm}^{3} \mathrm{~g}^{-1}$ respectively. Table 3 gives the chemical composition of SW PMMA before and after removal of MB and BY28. According to Table 3, it is observed that the SW PMMA does not contain nitrogen and the presence of $0.45 \%$ of sulfur is due to sulphonation reaction [11]. After removal, the percentages of these elements the increase in the surface of SW PMMA adsorbents revealed the adsorption of MB and BY28 dyes containing nitrogen, sulfur and oxygen atoms. On the other hand, the density of the SW PMMA increase can be explained by the adsorption of dyes onto the adsorbent surface. Significant differences in FTIR spectra of W PMMA and SW PMMA were observed in (Fig.3 (a)). The bands at 754 and $843 \mathrm{~cm}^{-1}$ are attributed to the methyl group vibrations and vibration of PMMA respectively. The bands at $1150 \mathrm{~cm}^{-1}$ and $1450 \mathrm{~cm}^{-1}$ can be attributed to the $\mathrm{C}-\mathrm{O}-\mathrm{C}$ stretching vibration and the $\mathrm{C}-\mathrm{H}$ bending (Alkane). The bands at $2360 \mathrm{~cm}^{-1}, 2997 \mathrm{~cm}^{-1}$ and $3437 \mathrm{~cm}^{-1}$ are assigned to the O$\mathrm{CH}_{3}$ stretching, the $\mathrm{C}-\mathrm{H}$ bond stretching vibrations of the $-\mathrm{CH}_{3}$ and the $-\mathrm{OH}$ groups stretching $[33,34]$. For the SW PMMA, a very wide band was observed in the region from $3087 \mathrm{~cm}^{-1}$ to $3654 \mathrm{~cm}^{-1}$ which is attributed to the stretching of the $\mathrm{SO}_{3} \mathrm{H}[11,35,36]$. Another absorption band occurred at approximately $1080 \mathrm{~cm}^{-1}-1271 \mathrm{~cm}^{-1}$, after sulphonation showing the presence of sulfonic groups in SW PMMA, which is assigned to sulfur-oxygen symmetric vibration $\mathrm{O}=\mathrm{S}=\mathrm{O}[35]$. The absorption at $1129 \mathrm{~cm}^{-1}$ results from a sulfonate anion attached to phenyl groups and the band identified at $1029 \mathrm{~cm}^{-1}$ to $1062 \mathrm{~cm}^{-1}$ results from the symmetric stretching vibration of $\mathrm{SO}_{3} \mathrm{H}$ groups $[10,11,37]$. Hence, the presence of the sulfonic groups in the SW PMMA was successfully confirmed by FTIR technique. Fig.3 (b) shows the FTIR 
spectra of SW PMMA before and after removal of MB and BY28 dyes. When closely examined these spectra, bands of sulfonic groups $\left(\mathrm{SO}_{3} \mathrm{H}\right.$ and $\left.\mathrm{O}=\mathrm{S}=\mathrm{O}\right)$ are visibly intense with slightly shifted position. This interpretation is in agreement with previous works $[11,12,35$, 36]. The surface morphology of SW PMMA before and after removal of MB and BY28 dyes were observed by SEM (Fig.4). The morphology of SW PMMA appears as layers modified by sulphonation reaction. After removal process, the traces of dyes are adsorbed on the surface of the SW PMMA layers without affecting their morphologies.

\subsection{Effect of physical parameters on $M B$ and BY28 removal}

\subsection{1. $\mathrm{pH}$ effect}

The effect of $\mathrm{pH}$ on the removal of MB and BY28 dyes on SW PMMA was studied in the range from 2 to 10 . The $\mathrm{pH}$ was adjusted to the required values by adding $\mathrm{HNO}_{3}(0.1 \mathrm{M})$ and $\mathrm{NaOH}(0.1 \mathrm{M})$. The obtained results are shown in (Fig.5(a)). It is observed that the removal percentage of MB and BY28 dyes increases with increasing $\mathrm{pH}$. The highest removal percentages are obtained at $\mathrm{pH} \sim 8$ for $\mathrm{MB}(62.41 \%)$ and at $\mathrm{pH} \sim 6$ for $\mathrm{BY} 28(95.38 \%)$. The ionic forms of MB and BY28 in aqueous solution are cationic. When the surface charge of the adsorbent is negative $(\mathrm{pH}>6)$, electrostatic attractive forces between the adsorbate and the adsorbent facilitate the adsorption of MB and BY28 on the SW PMMA surface [27]. At $\mathrm{pH}<6$, the SW PMMA is positively charged, and in this case, the adsorption efficiency decreases because the $\mathrm{H}^{+}$concentration is high and competes with cationic dyes for the same active sites available on the surface of SW PMMA.

\subsubsection{Effect of adsorbent dose}

The effect of the adsorbent dose on the removal MB and BY28 dyes on SW PMMA was evaluated from $0.2 \mathrm{~g} \mathrm{~L}^{-1}$ to $1 \mathrm{~g} \mathrm{~L}^{-1}$. The other parameters remained constant. Fig.5(b) shows the evolution of the removal percentages of MB and BY28 dyes on SW PMMA. It is observed 
that the increase in the adsorbent dose has a positive influence on the removal percentage. This is mainly due to the growth in the number of active sites available on the surface of the adsorbent [38]. In this way the optimal SW PMMA doses were $0.8 \mathrm{~g} \mathrm{~L}^{-1}(\mathrm{MB})$ and $0.4 \mathrm{~g} \mathrm{~L}^{-1}$ (BY28).

\subsubsection{Effect of temperature}

The influence of temperature on the removal percentages of MB and BY28 dyes onto SW PMMA was investigated in the range of $293 \mathrm{~K}$ to $333 \mathrm{~K}$, keeping the other parameters constant. According to (Fig.5(c)), the removal percentages of dyes decreases with increasing temperature from $85.27 \%$ to $32.49 \%$ for $\mathrm{MB}$ and $87.86 \%$ to $35.61 \%$ for BY28, suggesting an exothermic reaction [39].

\subsubsection{Effect of contact time and initial dyes concentration}

The effect of contact time on the removal of MB and BY28 on SW PMMA is shown in (Fig.5(d)) and (Fig.5(e)). The experiments were carried out with different initial dyes concentrations (40 mg L $\mathrm{m}^{-1}, 80 \mathrm{mg} \mathrm{L}^{-1}, 120 \mathrm{mg} \mathrm{L}^{-1}$ and $160 \mathrm{mg} \mathrm{L}^{-1}$ ) with $0.8 \mathrm{~g} \mathrm{~L}^{-1}$ adsorbent

mass for MB and $0.4 \mathrm{~g} \mathrm{~L}^{-1}$ for BY28 at $20 \pm 2{ }^{\circ} \mathrm{C}$. The analysis of these results shows that the adsorption kinetics of both dyes took place in two phases. The first is fast at the beginning of the adsorption due to the high availability of free active sites of SW PMMA; and the second becomes more and more slow over time to reach equilibrium. The equilibrium adsorption times are reached at $45 \mathrm{~min}$ and $30 \mathrm{~min}$ for $\mathrm{MB}$ and BY28 respectively. As can be seen from (Fig.5(d)) and (Fig.5(e)), a rise in the concentration from $40 \mathrm{mg} \mathrm{L}^{-1}$ to $160 \mathrm{mg} \mathrm{L}^{-1}$, indicates a decrease in the removal percentages from $99.88 \%$ to $48.52 \%$ for $\mathrm{MB}$ and from $93.71 \%$ to $53.17 \%$ for BY28 on SW PMMA adsorbent.

\subsection{Equilibrium study}


The adsorption isotherms play an important role in the determination of the maximum capacities and in the identification of the adsorption mechanism [30, 39]. Isotherms are obtained by plotting $\mathrm{q}_{\mathrm{e}}$ in terms of $\mathrm{C}_{\mathrm{e}}[40]$ and are depicted in (Fig.6). According to this figure the adsorption capacity of SW PMMA for both MB and BY28 dyes increases rapidly for low concentrations and then decreases to reach the corresponding equilibrium saturation of the adsorption sites. The isotherm obtained is of type $\mathrm{L}$ according to the classification of Giles which shows that the process of adsorption of the two dyes could occur in monolayers [41]. In addition, it is observed that the adsorption capacity of SW PMMA to removal of BY28 $\left(222.22 \mathrm{mg} \mathrm{g}^{-1}\right)$ is greater than $\mathrm{MB}\left(97.09 \mathrm{mg} \mathrm{g}^{-1}\right)$.

\subsubsection{Modeling of sorption isotherms}

Langmuir, Freundlich and Temkin models were applied to fit the experimental isotherms. To determine the most representative model, their original equations were linearized for the two dyes. The linearized equation for Langmuir model is as follows (Eq. 3) [42].

$\frac{\mathrm{C}_{\mathrm{e}}}{\mathrm{q}_{\mathrm{e}}}=\frac{1}{\mathrm{q}_{\max } \mathrm{K}_{\mathrm{L}}}+\frac{\mathrm{C}_{\mathrm{e}}}{\mathrm{q}_{\max }}$

Were $C_{e}$ is the equilibrium concentration of dye in solution $\left(\mathrm{mg} \mathrm{L}^{-1}\right), q_{e}$ the amount of dye adsorbed onto the adsorbent $\left(\mathrm{mg} \mathrm{g}^{-1}\right), q_{\max }$ maximum monolayer adsorption capacity $\left(\mathrm{mg} \mathrm{g}^{-1}\right)$ and $\mathrm{K}_{\mathrm{L}}$ is Langmuir constant $\left(\mathrm{L} \mathrm{mg}^{-1}\right)$. The separation factor parameter $\mathrm{R}_{\mathrm{L}}$ was calculated from (Eq. 4) [42] for the determination of the favorability of the adsorption process.

$\mathrm{R}_{\mathrm{L}}=\frac{1}{1+\mathrm{K}_{\mathrm{L}} \mathrm{C}_{0}}$

The values of $R_{L}$ relating the type of Langmuir isotherm which to be advantageous $\left(0<\mathrm{R}_{\mathrm{L}}<1\right)$, irreversible $\left(\mathrm{R}_{\mathrm{L}}=0\right)$, linear $\left(\mathrm{R}_{\mathrm{L}}=1\right)$ or unfavorable $\left(\mathrm{R}_{\mathrm{L}}>1\right)$. The linear form of the Freundlich isotherm is as follows (Eq. 5) [27]:

$$
\ln \mathbf{q}_{e}=\operatorname{Ln} K_{F}+\frac{1}{n_{F}} \operatorname{Ln} C_{e}
$$


Were $K_{F}$ and $n_{F}$ are Freundlich constants, associated respectively to the adsorption capacity $\left(\mathrm{mg} \mathrm{g}^{-1}\right)$ and adsorption intensity. Finally, the Temkin linear model is given by the following equation (Eq. 6) [30]:

$$
q_{e}=\frac{R T}{b_{T}} \operatorname{Ln} A_{T}+\frac{R T}{b_{T}} \operatorname{Ln} C_{e}
$$

Where $b_{T}$ is Temkin isotherm constant, $A_{T}$ is Temkin isotherm equilibrium binding constant $\left(\mathrm{L} \mathrm{g}^{-1}\right), R$ is the universal constant of perfect gases $\left(8.314 \mathrm{~J}\right.$ mole $\left.{ }^{-1} \mathrm{~K}^{-1}\right)$ and $T=$ Temperature at 298 K. According to the results shown in (Fig.7) and Table 4 the Langmuir and Temkin models were the most suitable for modelling the removal of MB dye on SW PMMA. The Langmuir adsorption model is also the most suitable model compared with Temkin and Freundlich for exhibiting the removal of BY28 dye on SW PMMA. The applicability of the Langmuir model indicates as a result the use of monolayer coverage theory of MB and BY28 dyes onto the surface of SW PMMA adsorbent. According to Table 5, the $\mathrm{R}_{\mathrm{L}}$ values for the adsorption of both MB and BY28 by SW PMMA demonstrate that the adsorption process is favorable. Table 6 shows different adsorbents used in recent works for the removal of MB and BY28 dyes and their adsorption capacities. SW PMMA seems to be very operative in removing MB and BY28 dyes from investigated aqueous solutions. From Table 6, comparing the adsorption capacities shows that the modified and treated waste PMMA with sulphonation reaction perform significantly [43-53].

\subsection{Adsorption kinetic}

Generally, the adsorption reaction involves the fixation of the solute on the active sites of the solid which is considered extremely fast. It the characteristics of the studied system such as external mass transfer, internal resistances, turbulence regime, concentration of the solution, 
porosity, specific surface area and the number of available active sites [39, 54]. To deduce the mechanism of the adsorption process, the adsorption kinetic is modeled at different concentrations by pseudo first (Eq. 7) and pseudo second (Eq. 8) orders [32, 55].

$$
\operatorname{Ln}\left(\mathbf{q}_{e}-\mathbf{q}_{\mathbf{t}}\right)=\operatorname{Ln} \mathbf{q}_{\mathbf{e}}-\mathbf{k}_{1} \mathbf{t}
$$

From the graphical representation of $\operatorname{Ln}\left(\mathrm{q}_{\mathrm{e}}-\mathrm{q}_{\mathrm{t}}\right)$ versus time $(\mathrm{t})$ at different concentrations, $k_{1}$ $\left(\min ^{-1}\right)$ the pseudo first order kinetic constant and $q_{e}$ can be determined.

$\frac{t}{q_{t}}=\frac{1}{k_{2} q_{e}^{2}}+\frac{1}{q_{e}} t$

The pseudo second order constant rate $k_{2}\left(\mathrm{~g} \mathrm{mg}^{-1} \mathrm{~min}^{-1}\right)$ and $q_{e}$ are determined from the intercept and the slope of the line represents $\mathrm{t}_{\mathrm{t}}^{-1}$ versus $\mathrm{t}$. From the obtained results shown in (Fig.8) and Table 7, it can be established that the pseudo second order model is the most reliable for determining the order of adsorption kinetics of the two dyes MB and BY28 onto SW PMMA with a good correlation coefficient $\left(\mathrm{R}^{2}>0.9939\right)$. Similarly, it was observed that the $\mathrm{q}_{\mathrm{e}}$ values calculated by the pseudo second order model Table 7 are very close to those determined experimentally.

\subsection{Thermodynamic study}

The thermodynamic parameters of the adsorption process, free Gibbs enthalpy $\Delta \mathrm{G}^{\circ}\left(\mathrm{J} \mathrm{mol}^{-1}\right)$, enthalpy $\Delta \mathrm{H}^{\circ}\left(\mathrm{kJ} \mathrm{mol}^{-1}\right)$ and entropy $\Delta \mathrm{S}^{\circ}\left(\mathrm{kJ} \mathrm{mol}^{-1} \mathrm{~K}^{-1}\right)$ were determined to explain the mechanism of the MB and BY28 adsorption process onto SW PMMA. The variation of $\left(\Delta \mathrm{H}^{\circ}\right)$ and the $\left(\Delta S^{\circ}\right)$ can be obtained from the slope and the intercept of the $\operatorname{Ln} K_{d}$ plot as a function of $\left(1 \mathrm{~T}^{-1}\right)($ Eq. 9) see (Fig. 9).

$$
\operatorname{Ln} K_{d}=\left(\frac{\Delta S^{\mathbf{o}}}{R}\right)-\left(\frac{\Delta H^{0}}{R T}\right)
$$


Where $T$ is the absolute temperature $(\mathrm{K}), R$ is the universal gas constant $\left(8.314 \mathrm{~J} \mathrm{~mol}^{-1} \mathrm{~K}^{-1}\right)$ and $K_{d}\left(\mathrm{~L} \mathrm{~g}^{-1}\right)$ is the adsorption distribution coefficient expressed by Nibou et al and Mekatel et al $[31,56]$

$\mathbf{K}_{\mathbf{d}}=\frac{\mathbf{q}_{\mathrm{e}}}{\mathbf{C}_{\mathrm{e}}}$

The standard free energy $\left(\Delta \mathrm{G}^{\circ}\right)$ is expressed by Salvestrini et al (Eq. 11) [57]:

$\Delta \mathbf{G}^{\mathbf{0}}=\Delta \mathbf{H}^{\mathbf{0}}-\mathbf{T} \Delta \mathbf{S}^{\mathbf{o}}$

The values of the thermodynamic parameters are summarized in Table 8 . The negative values of $\Delta \mathrm{H}^{\circ}$ indicate that the adsorption process of MB and BY28 onto SW PMMA is exothermic. The $\Delta \mathrm{H}^{\circ}$ values suggest that the adsorption process is physical when the enthalpy values are less $40 \mathrm{~kJ} \mathrm{~mole}^{-1}[58,59]$. The results of Table 8 confirm this assumption. The $\Delta \mathrm{G}^{\circ}$ values for both dyes are negative for all tested temperatures confirming that the adsorption of $\mathrm{MB}$ and BY28 onto SW PMMA is thermodynamically favorable and spontaneous with high affinity. The $\Delta \mathrm{G}^{\circ}$ values were also less negative at increasing temperature suggesting that the equilibrium capacity decreased. In addition, the $\Delta S^{0}$ values were negative showing the decreased randomness at the SW PMMA-liquid interface during the MB and BY28 adsorption suggesting a stability of the dyes on the surface of SW PMMA.

\section{Conclusions}

In this work the recovery of waste PMMA to produce an efficient adsorbent used in the removal of MB and BY28 textile dyes was demonstrated. The SW PMMA prepared after sulphonation reaction was tested with success for the abatement of MB and BY28 dyes. FTIR analysis of SW PMMA revealed the sulphonic groups $\mathrm{SO}_{3} \mathrm{H}$ and $\mathrm{SO}_{2}$ which are responsible and contribute in the adsorption of the cationic dyes. SEM and chemical analysis characterization allowed observing the shape of SW PMMA as layers and to determine their 
compositions. The experimental optimized parameters (solution $\mathrm{pH}$, initial dyes concentration, adsorbent dose and temperature) were also determined. The experimental data were fitted to Langmuir, Freundlich and Temkin models and it was found that the equilibrium followed well the Langmuir adsorption isotherm for MB and BY28 dyes onto SW PMMA. This consequence indicates the formation of a monolayer of the MB and BY28 dyes on the surface of SW PMMA adsorbent. The adsorption data were used to exhibit the pseudo first order and pseudo second order equations. It was shown that the pseudo second order kinetic pronounced greatest the adsorption kinetic of MB and BY28 dyes onto SW PMMA. The thermodynamic parameters $\Delta \mathrm{H}^{\circ}, \Delta \mathrm{S}^{\circ}$ and $\Delta \mathrm{G}^{\circ}$ values have been determined. The negative values of $\Delta \mathrm{H}^{\circ}$ confirmed the exothermic adsorption nature of $\mathrm{MB}$ and $\mathrm{BY} 28$ onto $\mathrm{SW}$ PMMA. The negative values of $\Delta \mathrm{G}^{\circ}$ confirmed also the favorability and spontaneity of the adsorption process. The negative values of $\Delta \mathrm{S}^{\mathrm{o}}$ proved the stability of MB and BY28 dyes on the surface of SW PMMA. Comparison of the adsorption capacities of SW PMMA with other adsorbents reveals high adsorption capacities over MB (97.09 $\left.\mathrm{mg} \mathrm{g}^{-1}\right)$ and BY28 (222.22 mg $\mathrm{g}^{-1}$ ) and perform considerably.

\section{References}

1. Schwarzböck T, Van Eygen E, Rechberger H, Fellner J (2017) Determining the amount of waste plastics in the feed of Austrian waste-to-energy facilities. Waste Management \& Research $35: 207-216$

2. Gent MR, Menendez M, Toraño J, Diego I (2009) Recycling of plastic waste by density separation: prospects for optimization. Waste management \& research 27:175-187

3. Maris J, Bourdon S, Brossard J-M, et al (2017) Mechanical recycling: Compatibilization of mixed thermoplastic wastes. Polymer Degradation and Stability

4. Sharuddin SDA, Abnisa F, Daud WMAW, Aroua MK (2016) A review on pyrolysis of plastic wastes. Energy conversion and management 115:308-326

5. Bazargan A, Hui CW, McKay G (2013) Porous carbons from plastic waste. In: Porous CarbonsHyperbranched Polymers-Polymer Solvation. Springer, pp 1-25 
6. Popescu V, Vasile C, Brebu M, et al (2009) The characterization of recycled PMMA. Journal of Alloys and Compounds 483:432-436

7. Achilias DS (2006) Chemical recycling of polymers. The case of poly (methyl methacrylate). pp 8-10

8. Özdemir T, Usanmaz A (2009) Use of poly (methyl methacrylate) in radioactive waste management: II. Monte Carlo simulations. Progress in Nuclear Energy 51:845-848

9. Kučera F, Jančář J (1998) Homogeneous and heterogeneous sulfonation of polymers: a review. Polymer Engineering \& Science 38:783-792

10. Mulijani S, Dahlan K, Wulanawati A (2014) Sulfonated polystyrene copolymer: synthesis, characterization and its application of membrane for direct methanol fuel cell (DMFC). Int $J$ Mater, Mech Manuf 2:36-40

11. Ruziwa D, Chaukura N, Gwenzi W, Pumure I (2015) Removal of Zn2+ and Pb2+ ions from aqueous solution using sulphonated waste polystyrene. Journal of Environmental Chemical Engineering 3:2528-2537

12. Bekri-Abbes I, Bayoudh S, Baklouti M (2006) Converting waste polystyrene into adsorbent: potential use in the removal of lead and cadmium ions from aqueous solution. Journal of Polymers and the Environment 14:249-256

13. Kant $R$ (2012) Textile dyeing industry an environmental hazard. Natural science 4:22-26

14. Yagub MT, Sen TK, Ang H (2012) Equilibrium, kinetics, and thermodynamics of methylene blue adsorption by pine tree leaves. Water, Air, \& Soil Pollution 223:5267-5282

15. Pearce C, Lloyd J, Guthrie J (2003) The removal of colour from textile wastewater using whole bacterial cells: a review. Dyes and pigments 58:179-196

16. Estela DM, FÃ MM, Rosim FRT (2017) Degradation of textile dyes by cyanobacteria. Brazilian Journal of Microbiology

17. Rajaguru P, Suba S, Palanivel M, Kalaiselvi K (2003) Genotoxicity of a polluted river system measured using the alkaline comet assay on fish and earthworm tissues. Environmental and Molecular Mutagenesis 41:85-91

18. Mathur N, Bhatnagar P, Verma H (2006) Genotoxicity of vegetables irrigated by industrial wastewater. Journal of Environmental Sciences 18:964-968

19. Puvaneswari N, Muthukrishnan J, Gunasekaran P (2006) Toxicity assessment and microbial degradation of azo dyes

20. Tüfekci N, Sivri N, Toroz i (2007) Pollutants of textile industry wastewater and assessment of its discharge limits by water quality standards. Turkish Journal of Fisheries and Aquatic Sciences 7:

21. Liu R, Fu K, Zhang B, et al (2012) Removal of methyl orange by modified halloysite nanotubes. Journal of Dispersion Science and Technology 33:711-718

22. Ghaly A, Ananthashankar R, Alhattab M, Ramakrishnan V (2014) Production, characterization and treatment of textile effluents: a critical review. J Chem Eng Process Technol 5:1-19 
23. Gonçalves JO, Silva KA, Dotto GL, Pinto LA (2018) Adsorption Kinetics of Dyes in Single and Binary Systems Using Cyanoguanidine-Crosslinked Chitosan of Different Deacetylation Degrees. Journal of Polymers and the Environment 26:2401-2409

24. Konicki W, Aleksandrzak M, Mijowska E (2017) Equilibrium, kinetic and thermodynamic studies on adsorption of cationic dyes from aqueous solutions using graphene oxide. Chemical Engineering Research and Design 123:35-49

25. Raman CD, Kanmani S (2016) Textile dye degradation using nano zero valent iron: a review. Journal of Environmental Management 177:341-355

26. Kannan N, Sundaram MM (2001) Kinetics and mechanism of removal of methylene blue by adsorption on various carbons-a comparative study. Dyes and pigments 51:25-40

27. Mekatel E, Amorkrane S, Trari M, et al (2018) Combined Adsorption/Photocatalysis Process for the Decolorization of Acid Orange 61. Arabian Journal for Science and Engineering 1-12

28. Rodrigues DA, Moura JM, Dotto GL, et al (2018) Preparation, Characterization and Dye Adsorption/Reuse of Chitosan-Vanadate Films. Journal of Polymers and the Environment 1-8

29. Aid A, Amokrane S, Nibou D, et al (2018) Modeling biosorption of $\mathrm{Cr}$ (VI) onto Ulva compressa L. from aqueous solutions. Water Science and Technology 77:60-69

30. Samir L, Samira A, Mekatel E hadj, Djamel N (2018) Adsorption of Cr (VI) on Stipa tenacissima L (Alfa): Characteristics, kinetics and thermodynamic studies. Separation Science and Technology $1-12$

31. Nibou D, Mekatel H, Amokrane S, et al (2010) Adsorption of $\mathrm{Zn} 2+$ ions onto $\mathrm{NaA}$ and $\mathrm{NaX}$ zeolites: Kinetic, equilibrium and thermodynamic studies. Journal of Hazardous Materials 173:637-646

32. Haddad D, Mellah A, Nibou D, Khemaissia S (2018) Promising enhancement in the removal of uranium ions by surface-modified activated carbons: kinetic and equilibrium studies. Journal of Environmental Engineering 144:04018027

33. Duan G, Zhang C, Li A, et al (2008) Preparation and characterization of mesoporous zirconia made by using a poly (methyl methacrylate) template. Nanoscale research letters 3:118

34. Ghorbel E, Hadriche I, Casalino G, Masmoudi N (2014) Characterization of thermo-mechanical and fracture behaviors of thermoplastic polymers. Materials 7:375-398

35. Brandão LR, da Silva Meireles C, de Assunção RMN, Rodrigues Filho G (2005) Diffusion of Water through Poly (styrenesulfonate) membranes produced from the sulfonation of wasted PS plastic cups. Polymer Bulletin 55:269-275

36. Chaukura N, Mamba BB, Mishra SB (2017) Conversion of post consumer waste polystyrene into a high value adsorbent and its sorptive properties for Congo Red removal from aqueous solution. Journal of environmental management 193:280-289

37. Martins CR, Ruggeri G, De Paoli M-A (2003) Synthesis in pilot plant scale and physical properties of sulfonated polystyrene. Journal of the Brazilian Chemical Society 14:797-802 
38. Nibou D, Amokrane S, Mekatel H, Lebaili N (2009) Elaboration and characterization of solid materials of types zeolite $\mathrm{NaA}$ and faujasite $\mathrm{NaY}$ exchanged by zinc metallic ions $\mathrm{Zn} 2+$. Physics Procedia 2:1433-1440

39. Nibou D, Khemaissia S, Amokrane S, et al (2011) Removal of UO22+ onto synthetic NaA zeolite. Characterization, equilibrium and kinetic studies. Chemical engineering journal 172:296-305

40. Mekatel EH, Amokrane S, Aid A, et al (2015) Adsorption of methyl orange on nanoparticles of a synthetic zeolite $\mathrm{NaA} / \mathrm{CuO}$. Comptes Rendus Chimie 18:336-344

41. Amokrane S, Rebiai R, Nibou D (2007) Behaviour of Zeolite A, Faujasites X and Y Molecular Sieves in Nitrogen Gas Adsorption. Journal of Applied Sciences 7:1985-1988

42. Houhoune F, Nibou D, Chegrouche S, Menacer S (2016) Behaviour of modified hexadecyltrimethylammonium bromide bentonite toward uranium species. Journal of Environmental Chemical Engineering 4:3459-3467

43. Cao Y-L, Pan Z-H, Shi Q-X, Yu J-Y (2018) Modification of chitin with high adsorption capacity for methylene blue removal. International journal of biological macromolecules 114:392-399

44. Azadeh E, Seyed F, Ardovan Y (2015) Surfactant-modified wheat straw: preparation, characterization and its application for methylene blue adsorption from aqueous solution. J Chem Eng Process Technol 6:231

45. Mouni L, Belkhiri L, Bollinger J-C, et al (2018) Removal of methylene blue from aqueous solutions by adsorption on kaolin: kinetic and equilibrium studies. Applied Clay Science 153:3845

46. Boudechiche N, Mokaddem H, Sadaoui Z, Trari M (2016) Biosorption of cationic dye from aqueous solutions onto lignocellulosic biomass (Luffa cylindrica): characterization, equilibrium, kinetic and thermodynamic studies. International Journal of Industrial Chemistry 7:167-180

47. Gürses A, Hassani A, Kıranşan M, et al (2014) Removal of methylene blue from aqueous solution using by untreated lignite as potential low-cost adsorbent: kinetic, thermodynamic and equilibrium approach. Journal of Water Process Engineering 2:10-21

48. Konicki W, Cendrowski K, Bazarko G, Mijowska E (2015) Study on efficient removal of anionic, cationic and nonionic dyes from aqueous solutions by means of mesoporous carbon nanospheres with empty cavity. Chemical Engineering Research and Design 94:242-253

49. Cheknane B, Bouras O, Baudu M, et al (2010) Granular inorgano-organo pillared clays (GIOCs): Preparation by wet granulation, characterization and application to the removal of a Basic dye (BY28) from aqueous solutions. Chemical Engineering Journal 158:528-534

50. Turabik M (2008) Adsorption of basic dyes from single and binary component systems onto bentonite: Simultaneous analysis of Basic Red 46 and Basic Yellow 28 by first order derivative spectrophotometric analysis method. Journal of hazardous materials 158:52-64

51. Olgun A, Atar N (2009) Equilibrium and kinetic adsorption study of Basic Yellow 28 and Basic Red 46 by a boron industry waste. Journal of Hazardous Materials 161:148-156

52. Tehrani-Bagha A, Nikkar H, Mahmoodi N, et al (2011) The sorption of cationic dyes onto kaolin: Kinetic, isotherm and thermodynamic studies. Desalination 266:274-280 
53. Yener J, Kopac T, Dogu G, Dogu T (2006) Adsorption of Basic Yellow 28 from aqueous solutions with clinoptilolite and amberlite. Journal of Colloid and Interface Science 294:255-264

54. Barkat M, Nibou D, Chegrouche S, Mellah A (2009) Kinetics and thermodynamics studies of chromium (VI) ions adsorption onto activated carbon from aqueous solutions. Chemical Engineering and Processing: Process Intensification 48:38-47

55. Krobba A, Nibou D, Amokrane S, Mekatel H (2012) Adsorption of copper (II) onto molecular sieves NaY. Desalination and Water Treatment 37:31-37

56. Mekatel H, Amokrane S, Benturki A, Nibou D (2012) Treatment of polluted aqueous solutions by $\mathrm{Ni2}+, \mathrm{Pb} 2+, \mathrm{Zn} 2+, \mathrm{Cr}+6, \mathrm{Cd}+2$ and $\mathrm{Co}+2$ lons by ion exchange process using faujasite zeolite. Procedia engineering 33:52-57

57. Salvestrini S, Leone V, lovino P, et al (2014) Considerations about the correct evaluation of sorption thermodynamic parameters from equilibrium isotherms. The Journal of Chemical Thermodynamics 68:310-316

58. Chatterjee S, Woo SH (2009) The removal of nitrate from aqueous solutions by chitosan hydrogel beads. Journal of hazardous materials 164:1012-1018

59. Barkat M, Nibou D, Amokrane S, et al (2015) Uranium (VI) adsorption on synthesized $4 \mathrm{~A}$ and P1 zeolites: Equilibrium, kinetic, and thermodynamic studies. Comptes Rendus Chimie 18:261-269 